Pre-review draft for discussion - October 2020. This paper has not yet been peer reviewed. Please do not copy or cite without author's permission. This paper is part of the WILDS Project, supported by UK Defra Illegal Wildlife Trade Challenge Fund (https://jacobphelps.wixsite.com/wilds).

\title{
A global taxonomy of wildlife offences
}

\author{
Maria Pascual $^{1}$, Jacob Phelps ${ }^{2 *}$, Jim Wingard ${ }^{1}$, Naila Bhatri ${ }^{3}$, Alyona Rydannykh ${ }^{4}$ \\ ${ }^{1}$ Legal Atlas, 1001 E. Broadway Stop 2 (PMB 322), Missoula, MT 59802, USA \\ ${ }^{2}$ Lancaster Environment Centre, Lancaster University LA1 4YQ, UK \\ ${ }^{3} 1055$ High Street Apt 203 Eugene, Oregon 97401, USA \\ ${ }^{4} 21$ Ilia Chavchavadze Avenue, 0179 Tbilisi, Georgia \\ *jacob.phelps@gmail.com
}

Keywords: environmental law, crime, enforcement, green criminology, comparative law, governance, illegal wildlife trade

\begin{abstract}
Environmental laws are ubiquitous, including to the field of conservation where they define how wildlife can be legally used, managed and protected. However, debates about environmental law regularly overlook the details within national legislation that define which specific acts are illegal, where laws apply, and how they are sanctioned. Based on a review of nearly 200 wildlife laws in 8 countries, we developed a taxonomy that describes all types of wildlife offences in those countries. The 511 offences are organized into a hierarchical taxonomy that scholars and practitioners can use to help conduct legal analyses globally, providing more nuance and facilitating like-for-like comparisons of laws across countries. This is significant amidst competing calls to strengthen, deregulate and reform wildlife legislation, particularly in response to fears over zoonotic threats and large-scale biodiversity loss. The taxonomy can be used to analyse legal reforms (e.g., new laws, deregulation, closing loopholes, harmonising legislation), or to establish international standards. For example, we apply the taxonomy to compare how 8 countries sanction the offence of "hunting a protected species", to explore different scales and approaches to imposing fines and imprisonment. The taxonomy also illustrates how future legal taxonomies can be developed in the environment sector.
\end{abstract}

\section{Introduction}

\section{Conservation is backed by law}

Environmental protection and natural resource laws exist globally, and include numerous provisions that govern how wildlife can be used, managed and protected. There are recurrent calls to strengthen and reform many of these laws, particularly amidst growing fears over zoonotic threats and large-scale biodiversity loss. For example, there are recent proposals to restrict wildlife trade and markets (Boyle 2020). There have also been calls to treat wildlife trade as a serious and organised crime (e.g., UK 2019); to strengthen domestic legislation to better meet international conservation commitments (e.g., CITES and UNEP 2015), and to update lists of protected wildlife species (e.g., Chng 2015). There are also calls to further "experiment" with using existing laws in order to more proactively respond to contemporary environmental challenges (e.g., Garmestani et al.2019). Equally, there are notable contemporary driving deregulation, including of the U.S. Endangered Species Act (Friedman 2019) and of multiple environmental regulations in Brazil (Spring 2020). Both patterns are occurring against a backdrop of growing concern about how regulation affects not only the environment, but also economy and humans. For example, there is broad concern that over-criminalization of wildlife laws can have negative and unethical impacts on local residents, park rangers and biodiversity (Brockington and Duffy 2019; Duffy et al. 2019). This has prompted calls for reforms to allow for legal, sustainable use of some wildlife species (e.g., Challender et al. 2015). These debates reflect a wide body of work on the complex relationships between law, conservation, enforcement, equity and behaviour, with a 
diversifying range of contributions (e.g., green and conservation criminology, Kurland et al. 2017; Borrato and Gibbs 2019).

However, across contexts and disciplines, debates about environmental laws and their enforcement often overlook the legal mechanics--the details of national legislation that define which acts are (il)legal, the conditions under which they apply, and how they are sanctioned. Laws can only be operationalized by ministerial officials, prosecutors and judges in the context of these legal details. Moreover, whether trying to better utilize, tighten, relax or reform legislation, there is a need to specifically define exactly which acts will be limited, allowed or reformed. For example, a call to "ban wildlife trade" could require revisions and clarifications affecting dozens of human actions whose legality is codified across many different areas of laws (e.g., international commerce, wildlife harvest, internet marketing, quarantine rules).

Few tools are available to help scholars and practitioners to identify, define, analyse and systematically compare illegal acts in the environment sector. This is important because both technical terminology, legal approaches and wildlife rules vary widely across contexts, legal traditions and jurisdictions (see Van Hoecke and Warrington 1998). Moreover, environmental law involves a broad range of legislation and mandates (e.g., harvests, technologies, welfare, import and export, and quarantine). This can challenge practitioners, who often lack legal training, and even legal professionals whose expertise is often limited to specific sectors and jurisdictions. As discussed below, this restricts efforts to innovate, learn lessons across jurisdictions and ensure legal reforms are thorough and specific.

\section{Purposes of taxonomies}

Global taxonomies provide a common lexicon and discrete categories to facilitate communication, collaboration and harmonization across cultures, languages and jurisdictions, as well as to understand where there is divergence. Taxonomies are a familiar concept in conservation, where classification and naming based on similarities and differences is often a baseline step in efforts for effective management (Thomson et al. 2018). Similarly, across criminology, customs, banking, information systems and law, taxonomies provide harmonized concepts and definitions that facilitate communication, comparisons and decisionmaking. For example, the United Nations Organisation on Drugs and Crime's International Classification of Crime for Statistical Purposes was developed to enable consistent criminal statistics on reporting and analyses for core areas of criminal law (although wildlife law; Bisogno et al. 2015). The World Customs Organisation deploys the Harmonized Commodity Description and Coding System to name and number $>5,000$ categories that are used to describe millions of products traded globally (WCO 2020).

For the legal field, taxonomies provide the "devices", "grammar" and "common dictionary" that improve access, enable translation, and support comparison within and across systems (Mattei 1997; Bisogno et al, 2015). Legal taxonomies often focus on how countries organise their laws (e.g., Mattei 1997; Sherwin 2009), but can also be used to organise legislation around specific topics (e.g., cybercrimes, Land et al. 2013). They are a cornerstone of legal analysis within a country, which often requires the sorting of rules in ways that allow generalisations (Sherwin 2009) or facilitate access to all laws that may apply to a certain concept. As such, taxonomies can help to identify laws that might be useful in a certain case, that represent loopholes, or that need updating.

In comparative law, taxonomies are a "prerequisite to make the knowledge and the problem-solving experience acquired in one system of law understandable and possibly transferable to another" (Mattei 1997), such as understanding how other jurisdictions are tackling challenging issues (e.g., wildlife cybercrime). Comparative law can serve to distinguish legal approaches among countries, or to identify the types of laws that might be considered as part of a legal revision. Taxonomies can also inform harmonization efforts of legislation across systems (e.g. across the European Union, see Law 2011); help standardise global reporting (e.g., Bisogno et al. 2015), and facilitate information-sharing and law enforcement cooperation (Land et al. 2013). Importantly, these efforts require an underlying taxonomy that names and categories diverse legal concepts. 


\section{First taxonomy of wildlife offences}

This study provides a globally-relevant taxonomy of types of legal offences related to terrestrial wild fauna, drawing on a structured review of nearly 200 laws in 8 countries (SI Appendix S1). It serves to parse the laws governing wildlife (e.g., Fig. 1), and presents a hierarchically-structured framework that can be used to analyse and compare wildlife laws and sanctions across countries. For example, we apply the taxonomy to compare how the 8 countries sanction the offence of hunting a protected species, to demonstrate how this resource can facilitate legal analysis and comparative law to inform wildlife conservation.

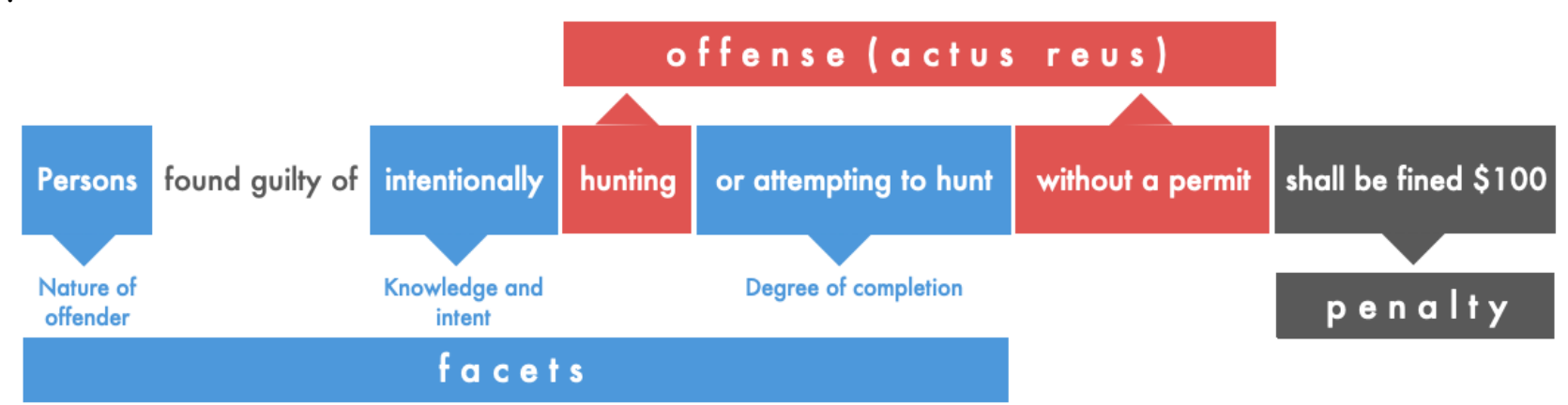

Figure 1. Anatomy of a legal provision, including offence, facets and penalty.

While there are a number of databases that compile wildlife legislation, these are limited to the identification of basic content and keyword searches (e.g., US Library of Congress' Law Library, VLex Justis, Codices, Fastcase's Public Library of Law). Concept-driven legal taxonomies remain rare in environmental law, conservation and wildlife. However, they are important part of legal analysis, development and reform, as well as debates about how laws affect environmental and social outcomes.

For example, domestically, structured analysis and comparisons of wildlife legislation can help to identify gaps and drafting mistakes. It can also reveal internal conflicts, such as where one law prohibits certain action, but another law provides permissions, or where sanctions across different pieces of legislation fail to match. This type of analysis can also identify sites where law may allow certain types of wildlife management, but where there are no established standards and procedures that would be required in order to operationalise the law. Related gaps can limit implementation and prosecution, and limit a country's ability to cooperate across jurisdictions (e.g. in international wildlife trade, dual criminality). Domestic analysis can also identify "untapped" opportunities within existing laws that are not traditionally used, but could be innovatively applied to address wildlife conservation (cf. Garmestani et al 2019).

International comparisons can reveal fundamentally different approaches to governing wildlife. For example, although some countries have comparatively broad regulations that rely heavily on prohibitions, others enable wildlife management and use according to specific requirements. These differences map onto distinctions between use or non-use of wildlife that are often central to conservation debates, and which are deeply shaped by national and international legislation. International comparison can also identify gaps by revealing how other countries have legislated similar situations. Comparative analysis can further inform discussions about international standards, and whether attempts at legal harmonization are appropriate and viable (cf. CITES and UNEP 2015). Such harmonization of conservation legislation could serve to uphold minimum standards, improve coordination, and close loop-holes (see Pennings 2004), but face many limitations across different political-cultural and economic contexts (cf. climate change legislation, Harring et al. 2019).

For example, in Indonesia a coalition of NGOs are helping to update the Natural Resources Conservation Law) with reforms to address online wildlife trade, strengthen sanctions and update the protected species list (Gokoon 2018). Comparative legal analysis facilitated by a legal taxonomy can help to identify how these types of issues have been legislated in other countries, and help contextualist Indonesian sanctions relative to those of neighbouring countries. The People Not Poaching initiative (https://www.peoplenotpoaching.org) is a knowledge-sharing platform to share solutions to wildlife trade based on community empowerment. Legal 
analysis can help identify and compare the rights allocated to communities in different countries, as well as provide a legal basis for exploring the social equity implications of legal sanctions for hunting protected species in different countries. In Thailand, TRAFFIC, the wildlife monitoring network is lobbying to close legal loop-holes that have left non-native threatened species unprotected (TRAFFIC 2016); a legal taxonomy can help to identify the aspects of which different laws need to be updated in order to address this gap. In Somalia, Somaliland, Yemen, and Ethiopia, the Cheetah Conservation Fund and its partners are working to expand and strengthen conservation legislation (CCF 2019); a legal taxonomy can help identify the legal approaches and types of laws that might be considered as part of a revision. Across these contexts, structured legal analysis and like-for-like comparisons with other jurisdictions are important to informing scholarship and practice.

\section{Methods}

We developed the taxonomy based on an analysis of the wildlife laws of eight, purposely-selected countries: Angola, Brazil, Cambodia, Costa Rica, Indonesia, Kenya, Mexico, and Vietnam. These were chosen to reflect a range of conservation priority countries with differing legal systems (Table 1) to ensure that a diversity of illegal actions associated with wildlife trade were included in the dataset, and to avoid the USand Euro-centric tendencies of many legal taxonomies (Mattei 1997). The research broadly followed steps described in Land et al. (2013), first collecting all relevant laws from each country, and determining the meta-characteristics of the law by organising all wildlife offences from the source material. We then evaluated these using an "empirical to conceptual" approach, where offences were sorted according to language and common characteristics, and then grouped into conceptual clusters of offences. This was then used to develop the typology, which was tested and expanded, including through trialling pieces of natural law to see how it fits. This generates a working taxonomy that is likely to continue evolving (Land et al. 2013).

Table 1. Legal foundations of the 8 sampled countries, and the number of laws and candidate terms

\begin{tabular}{|c|c|c|c|c|c|c|c|c|}
\hline & Angola & Brazil & Cambodia & $\begin{array}{c}\text { Costa } \\
\text { Rica } \\
\end{array}$ & Indonesia & Kenya & Mexico & Vietnam \\
\hline \multicolumn{9}{|l|}{ Legal foundations } \\
\hline Customary & $\mathrm{X}$ & & $\mathrm{X}$ & & $X$ & $\mathrm{X}$ & & $X$ \\
\hline Napoleanic & & & $X$ & $X$ & & & $X$ & $X$ \\
\hline British/Common & & $\mathrm{X}$ & & $X$ & & $\mathrm{X}$ & $\mathrm{X}$ & \\
\hline Sharia & & & & & $X$ & $X$ & & \\
\hline Roman & & $X$ & & & & & $X$ & \\
\hline Portuguese & $X$ & $X$ & & & & & & \\
\hline Spanish & & & & & & & $X$ & \\
\hline Dutch & & & & & $X$ & & & \\
\hline Soviet & & & & & & & & $X$ \\
\hline $\begin{array}{l}\text { Number of laws in } \\
\text { analysis (\# reviewed) }\end{array}$ & $8(18)$ & $13(20)$ & $5(14)$ & $9(18)$ & $13(29)$ & $16(45)$ & $12(24)$ & $14(26)$ \\
\hline $\begin{array}{l}\text { Candidate terms } \\
\text { contributed }\end{array}$ & 170 & 130 & 139 & 141 & 239 & 258 & 144 & 87 \\
\hline
\end{tabular}

"Table S2 includes a full list of legal sources and the laws collected for each country

\section{Approach to comparative law}

There are different approaches to developing typologies (see Land et al, 2013), and specifically for organising law and legal concepts (Sherwin 2009). This manuscript adopts a formal approach that "organizes law according to a set of structural rules" in a descriptive way and with an aim of clarification, overview and coherence (cf. Sherwin 2009). It focuses on what is empirically observable in pieces of legislation. This approach has clear limitations, including critiques against crude classification of the complexities inherent to law (Waddams in Law et al. 2013); debates about what might be considered moral, superior or socially legitimate (see Beyleveld and Brownsword 1985), and a recognition that comparative law gains most when it considers context and unique legal styles (Van Hoecke and Warrington 1998). Laws, as they are written, 
reflect only a small part of environmental governance and everyday practices; top-down legal frameworks are regularly interrogated and reshaped, and de jure realities often differ from codified rules (see Cleaver 2017). Moreover, there is growing recognition of the need to incorporate diverse values and ontologies into governance that are often overlooked in mainstream legislation (Diaz et al. 2015).

Nevertheless, our approach responds to the ubiquity and hegemony of formal wildlife law. However imperfect, it not only provides protection to species and individuals, but also helps shape the rights, livelihoods, opportunities and identities of people globally. Our focus on formal rules seeks to inform not only traditional legal processes and academic scholarship, but provides tools that will facilitate others unpacking the formal rules--including to contest them.

\section{Compilation of legislation}

For each of the eight sampled countries, we searched for legislation associated with 44 "types" or subjects of law that previous experience has demonstrated can refer to wildlife (Table S1; e.g., CITES implementing legislation, protected area laws, administrative and criminal codes, anti-money laundering, cybercrime, export laws). Subordinate implementing regulations were also collected (e.g., laws such as a Wildlife and Hunting Act, which might introduce what actions are considered offences, are typically accompanied by a Wildlife and Hunting Regulation that sets out specifics needed to implement the act). Laws were first sourced from official government websites but, as many countries lack a centralized system for compiling legislation, laws were also compiled from online legal sources (Table S2). In total, 194 pieces of legislation were compiled and reviewed to check if they matched our inclusion criteria: whether they related to terrestrial fauna (fisheries, flora, and timber were excluded due to the scale of the analysis), and whether they included direct reference to illegal acts or penalties. This yielded a list of 90 pieces of legislation (Table 1, Table S2). Although systematic review protocols are increasingly formalised in conservation (e.g., PRISMA), they are not established in the legal field; our objective here is thoroughness in terms of saturation, to create a nearly-exhaustive list of offences.

Collection and analysis of laws was conducted by researchers at Legal Atlas between November-June 2019. Legal Atlas ${ }^{\circledR}$ (www.legal-atlas.net) is an online legal platform that combines comparative legal analysis and technology to help inform legal scholarship and practise, and policy reform across topics contexts (e.g., access to information, corruption, organized crime, environmental crime, environmental impact assessments, money laundering, and mining).

\section{Data extraction}

We extracted the exact wording used to express each wildlife offence, focusing on the verb that described a specific, identifiable illegal act (indexing process, see ANSI/NISO 2005). We followed a set of protocols for dealing with common challenges that emerge when comparing laws across countries (Table S3).

The process drew on the standard elements in the anatomy of a legal provision (Fig. 1). Despite significant variability, legislation consistently includes a description of the illegal act (actus reus).They also include facets that further define or qualify the illegal act (e.g., time, place, status of completion, knowledge or intent of the responsible party); serve to identify the victim (e.g., protected species vs. non-protected), and can determine who may be held liable for an offences (e.g., persons, government officials, and legal entities) (e.g., Fig. 1; see ANSI/NISO2005). Offence provisions typically also include the sanctions that apply.

That process yielded a list of 1,548 candidate terms that described a variety of illegal acts. Most terms (62\%) were identified in English; the rest were translated from Spanish and Portuguese using Google Translate and checked by researchers fluent in both languages. We also used a thesaurus to identify additional synonyms (following ANSI/NISO 2005). We interpreted the legal concept expressed by each term, clustered them, identified synonyms and removed equivalent terms (semantic analysis, cf. ANSI/NISO 2005; Table S3). For example, the concept of "illegal hunting" was represented in legislation by 33 terms involving 15 different verbs, which were treated as synonyms. Terms that appeared most frequently in the dataset were selected as the preferred term (cf. ANSI/NISO Z39.19). 
Legal provisions that contained the candidate terms were then also reviewed for "facets" (Fig. 1). Facets enable the taxonomy to focus on the base criminal act, without losing the comparative and analytical understanding held by the facets. Review of the legislation revealed nine common categories of recurring facets (Table 2). We further identified the types of sanctions that applied to each offence we identified, and the aggravating or mitigating circumstances the defined the scope and scale of sanctions that apply for any given offence.

Table 2. Key facets of wildlife offences associated with the nature of the offence, offender, victim

\begin{tabular}{|c|c|c|}
\hline Facet & Definition & Dimensions \\
\hline \multicolumn{3}{|l|}{ Offence } \\
\hline Motivation & $\begin{array}{l}\text { Perpetrators' different potential motives for } \\
\text { participating in a particular offence. }\end{array}$ & $\begin{array}{l}\text { Profit or commercial gain } \\
\text { Thrill or sport } \\
\text { Necessity of obtaining food } \\
\text { Tradition \& cultural reasons }\end{array}$ \\
\hline Location & $\begin{array}{l}\text { Geographical delimitations to offences by } \\
\text { determining if a particular act has been } \\
\text { committed inside or outside a protected area }\end{array}$ & $\begin{array}{l}\text { Inside protected area } \\
\text { Outside protected area }\end{array}$ \\
\hline $\begin{array}{l}\text { Degree of } \\
\text { completion }\end{array}$ & $\begin{array}{l}\text { Takes into account whether a particular } \\
\text { criminal act has been planned, attempted or } \\
\text { completed, and these different degrees of } \\
\text { completeness may result in different } \\
\text { consequences of the act. }\end{array}$ & $\begin{array}{l}\text { Planned } \\
\text { Attempted } \\
\text { Completed }\end{array}$ \\
\hline \multicolumn{3}{|l|}{ Offender } \\
\hline $\begin{array}{l}\text { Nature of the } \\
\text { offender }\end{array}$ & $\begin{array}{l}\text { Can accommodate different levels of } \\
\text { liability for the same offence based on the } \\
\text { fact that the offender may be a physical } \\
\text { person, an entity or corporation, or a public } \\
\text { employee. }\end{array}$ & $\begin{array}{l}\text { Natural person } \\
\text { Legal person } \\
\text { Government official }\end{array}$ \\
\hline $\begin{array}{l}\text { Knowledge } \\
\text { and intent }\end{array}$ & $\begin{array}{l}\text { Offender's offender's state of mind when } \\
\text { committing the offence, given all the } \\
\text { circumstances and standards of what is } \\
\text { ordinarily considered prudent. }\end{array}$ & $\begin{array}{l}\text { Intentionally } \\
\text { Knowingly } \\
\text { Recklessness } \\
\text { Negligence } \\
\text { Gross negligence } \\
\end{array}$ \\
\hline $\begin{array}{l}\text { Degree of } \\
\text { Co- } \\
\text { responsibility }\end{array}$ & $\begin{array}{l}\text { Accommodates offences extending to those } \\
\text { persons besides the offender who also } \\
\text { participate in the offence, such as person } \\
\text { inciting to commit the offence, aiding or } \\
\text { abetting the offence, or just playing a role as } \\
\text { an accomplice. }\end{array}$ & $\begin{array}{l}\text { Incitement } \\
\text { Aiding or abetting } \\
\text { Accomplice }\end{array}$ \\
\hline \multicolumn{3}{|l|}{ Victim } \\
\hline Origin & $\begin{array}{l}\text { Accommodates segregation of offences if } \\
\text { they apply differently to wildlife harvested } \\
\text { within or outside a given jurisdiction (note } \\
\text { that this is distinct from whether a species is } \\
\text { native and non-native) }\end{array}$ & $\begin{array}{l}\text { Domestic } \\
\text { Foreign }\end{array}$ \\
\hline Legal status & $\begin{array}{l}\text { Whether legal protection is granted to the } \\
\text { species, expressed across legislation in } \\
\text { various ways (e.g., 'CITES Appendix I } \\
\text { species', 'listed species', 'rare species', or } \\
\text { 'species in danger of extinction'. }\end{array}$ & $\begin{array}{l}\text { Protected } \\
\text { Not protected }\end{array}$ \\
\hline Form & $\begin{array}{l}\text { The physical forms in which wildlife can } \\
\text { become the object of a given offence (e.g., } \\
\text { hunting offences may apply only to live } \\
\text { animals or eggs, while taxidermy-related }\end{array}$ & $\begin{array}{l}\text { Live } \\
\text { Eggs } \\
\text { Dead } \\
\text { Meat/Bush meat }\end{array}$ \\
\hline
\end{tabular}




\begin{tabular}{ll}
\hline $\begin{array}{l}\text { offences may apply to trophies, and } \\
\text { bushmeat trade may only to meat) }\end{array}$ & $\begin{array}{l}\text { Skins } \\
\text { Other parts } \\
\text { Products and derivatives } \\
\text { Trophies* }\end{array}$ \\
\hline *Trophies are presented within the facet of "form", and is also a core part of the taxonomy \\
when it refers to the activities of taxidermy and trophy dealing because these are distinct \\
actions in many countries' legislation.
\end{tabular}

\section{Categories in the taxonomy}

Iterative sorting and reduction resulted in a taxonomy with a 4-level hierarchical structure (see ANSI/NISO Z39.19; following Bisogno et al. 2015). Level 1 of the taxonomy was the broadest category, listing illegal actions associated with the harvest, transport, use of wildlife, forgery and obstruction of justice (corruption and organised crime were not included here). Each category was then further divided into mutuallyexclusive, sub-categories. In the Level 2 of the taxonomy, acts were sorted (where possible and appropriate) following a common pattern: (1) acts that are prohibited; (2) acts conducted without legal authorization (e.g., permitting, registration); (3) acts conducted in violation of authorized standard or procedures (e.g., quotas, size limits, transportation requirements, humanitarian standards) and (4) acts conducted with wildlife of an illegal origin. In addition, (5) a final catch-all category capturing "other acts in violation of the law related to...". This reflects a common legal drafting practice that involves a generic declaration intended to criminalize acts, even when they are not explicitly listed as offences in those sections of the law. Levels 3 and 4 of the taxonomy reflect further specificity of the acts, often informed by facets that define the conditions under which an act is illegal (see Fig. 1). Where we deduced that acts were missing from the taxonomy, we added these ( 7 acts), and where acts involved generic terms (e.g., importing goods) we made these specific to a wildlife context (e.g., importing wildlife).

\section{Results}

\section{Taxonomy of wildlife offences}

We developed a taxonomy that identifies and organizes all types of wildlife offences present in 8 highbiodiversity countries. It consists of 511 offence types, organized into a 4-level hierarchy, (e.g., Table 1; full taxonomy available as an Excels Sheet in Supplementary Information). Level 1 presents 16 broad categories of wildlife offence, and each subsequent level identifies a more specific offence (Table 1, e.g., Level 2 has 82 categories, Level 3 has 296 categories). Each offence is identified with a numeric code that consists of four numbers that refer to its position in the hierarchy (cf. ISO 2005). For example, in the code 02-03-003005 , the 02 refers to the second item in Level 1 of the taxonomy.

Table 3. Extract of the 4-level taxonomy, focused on offences related to the transportation of wildlife (Full taxonomy available as an Excels Sheet in Supplementary Information)

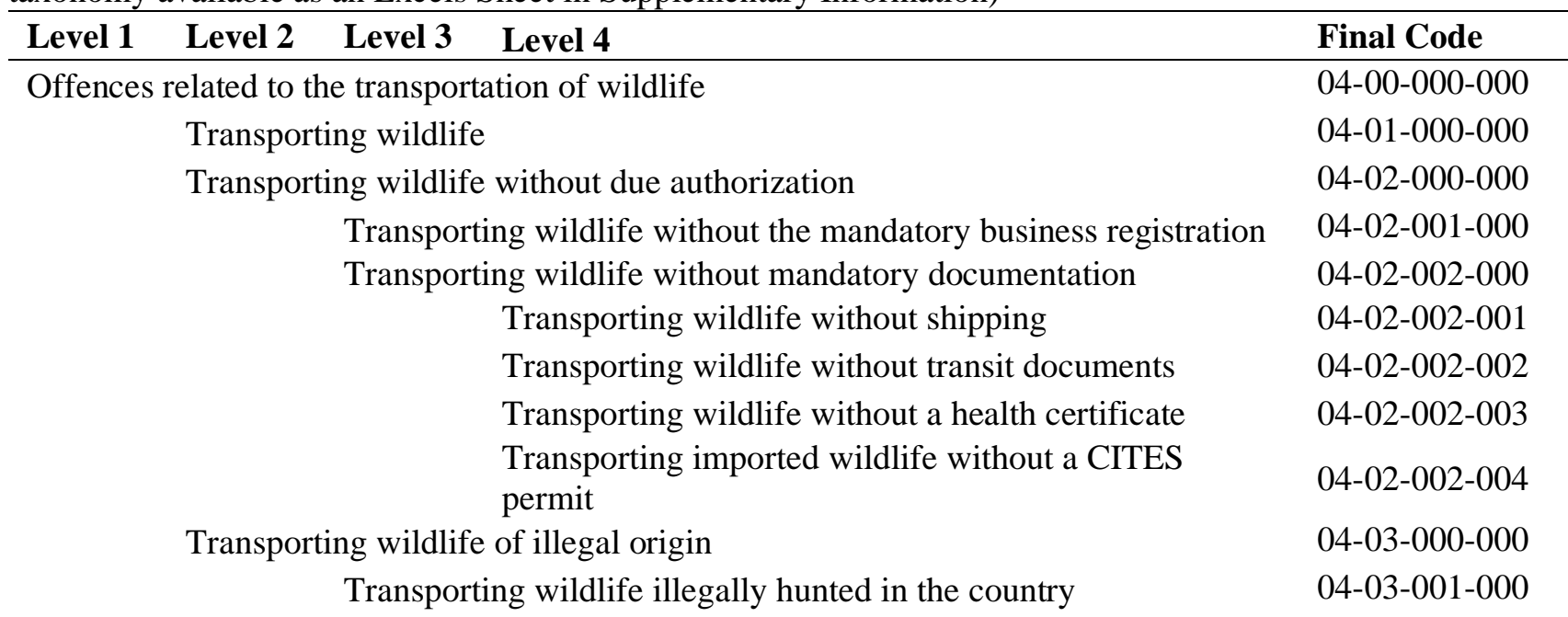


Transporting wildlife illegally hunted in a foreign country

04-03-002-000

Transporting wildlife illegally imported

04-03-003-000

Transporting Appendix I wildlife imported without CITES

04-03-004-000

certificate

Transporting wildlife sourced from unauthorized breeding site

04-03-005-000

Transporting wildlife illegally sold

04-03-006-000

Transporting wildlife illegally purchased

04-03-007-000

Transporting stolen wildlife

04-03-008-000

Transporting wildlife in breach of legal requirements and procedures

04-04-000-000

Transporting wildlife in improper receptacles

04-04-001-000

Transporting wildlife in overcrowded conditions

04-04-002-000

Transporting wildlife in amounts that exceed what is necessary for

04-04-003-000 customary use

Transporting wildlife that is unfit to be transported

04-04-004-000

Transporting wildlife injured or sick

04-04-004-001

Transporting wildlife that is likely to give birth during conveyance

04-04-004-002

Other acts in violation of the law related to the breach of legal provisions on

04-99-000-000 wildlife transportation

We found that the 511 types of offences were subject to diverse sanctions; we identified 17 categories of sanctions for wildlife offences, ranging from fines and incarceration to warning letters, license suspension and community serve (Table 4).

Table 4. Types of sanction imposed for wildlife offences.

\begin{tabular}{|c|c|}
\hline Category & Type of sanction \\
\hline \multirow[t]{2}{*}{ Economic sanctions } & Fines \\
\hline & Reimbursement of investigation or prosecution costs \\
\hline \multirow{3}{*}{$\begin{array}{l}\text { Related to the } \\
\text { wildlife specimen(s) }\end{array}$} & Confiscation or seizure of affected wildlife \\
\hline & Cost of the repatriation of a non-native specimens \\
\hline & Destruction of the specimens \\
\hline \multirow[t]{5}{*}{ Limit on rights } & $\begin{array}{l}\text { Revocation of, and/or ban on future rights, permits and } \\
\text { licenses }\end{array}$ \\
\hline & Suspension or ban of right to hold a public position \\
\hline & Suspension or ban of corporate activities \\
\hline & Loss of corporate custom benefits and incentives \\
\hline & Loss of corporate right to conduct customs activities \\
\hline \multirow{4}{*}{$\begin{array}{l}\text { Loss of personal } \\
\text { freedom }\end{array}$} & Criminal imprisonment \\
\hline & Administrative arrest \\
\hline & Community service \\
\hline & Deportation of foreign offenders \\
\hline \multirow{2}{*}{$\begin{array}{l}\text { Orders to remedy } \\
\text { environmental harm }\end{array}$} & Environmental restoration (e.g., costs of reintroduction) \\
\hline & Financial compensation/indemnification for harm \\
\hline \multirow[t]{2}{*}{ Information } & Warning letter \\
\hline & $\begin{array}{l}\text { Inscription in the public register of environmental } \\
\text { offenders }\end{array}$ \\
\hline
\end{tabular}

We also identified 5 categories of common aggravating and mitigating circumstances that informed the scale of those sanctions (Table 5). For example, an illegal act that caused specific types of harm might receive greater sanctions, or an offender's circumstance (e.g., young age) might result in reduced sanctions. 
Table 5. Types of aggravating and mitigating circumstances the define the scope and scale of sanctions that apply for any given offence.

\begin{tabular}{|c|c|}
\hline Category of circumstance & $\begin{array}{l}\text { Aggravating and mitigating circumstances } \\
\text { (i.e. whether the offence caused or depended on the following) }\end{array}$ \\
\hline $\begin{array}{l}\text { Type of harm caused by the } \\
\text { offence }\end{array}$ & $\begin{array}{l}\text { Caused harm to public security } \\
\text { Caused harm to public health } \\
\text { Caused harm to the broader ecosystem/environmental } \\
\text { Caused harm to private property } \\
\text { Caused harm to fauna that was irreversible } \\
\text { Caused harm to multiple individuals (number of specimens) } \\
\text { Caused harm to species that were protected }\end{array}$ \\
\hline $\begin{array}{l}\text { Technical characteristics of } \\
\text { the offence (e.g., methods, } \\
\text { time, place) }\end{array}$ & $\begin{array}{l}\text { Used methods of mass destruction } \\
\text { Used cruel methods } \\
\text { Used illegal methods } \\
\text { Used aerial, terrestrial or river transportation } \\
\text { Used weapons } \\
\text { Used violence } \\
\text { Used coercion } \\
\text { Used false documents } \\
\text { Occurred inside protected areas or other areas where it is prohibited to hunt } \\
\text { Occurred inside areas under legal protection } \\
\text { Occurred inside wilderness areas } \\
\text { Occurred inside an urban area } \\
\text { Occurred at night } \\
\text { Occurred in times of drought or flood } \\
\text { Occurred during closed hunting seasons } \\
\text { Occurred on Sundays or public holidays } \\
\text { Occurred using fraud or involving breach of trust } \\
\text { Took improper advantage of authority } \\
\text { Involved corrupt officers } \\
\text { Took advantage of national disasters, wars, states of emergency } \\
\text { Occurred in breach of the terms of a license } \\
\text { If continued crime } \\
\text { Was of international nature } \\
\text { Involved minors }\end{array}$ \\
\hline $\begin{array}{l}\text { Economic characteristics of } \\
\text { the offence }\end{array}$ & $\begin{array}{l}\text { Depending on the monetary value of the affected wildlife } \\
\text { Depending on the scale of the gain, benefit or estimated proceeds from the } \\
\text { crime }\end{array}$ \\
\hline Offender's circumstances & $\begin{array}{l}\text { Involved recidivism (repeat offending) } \\
\text { Depending on offender's age } \\
\text { Depending on offender's criminal past record } \\
\text { Depending on offender's educational level } \\
\text { Depending on offender's economic condition } \\
\text { Depending on offender's social condition } \\
\text { Depending on offender's psychological and psychiatric condition } \\
\text { Involved a professional hunter } \\
\text { Involved a legal entity } \\
\text { Involved a public officer } \\
\text { Involved a legal guardian of the wildlife resource } \\
\text { Involved an organized group } \\
\text { Involved an indigenous person with traditional uses for wildlife }\end{array}$ \\
\hline Offender's degree of intent & $\begin{array}{l}\text { Demonstrated negligence } \\
\text { Demonstrated intent } \\
\text { Made the offender profit or was motivated by commercial profit }\end{array}$ \\
\hline
\end{tabular}


Was done in the interest of a legal entity that was a beneficiary of public funds or tax incentives

Depending on the offender's behaviour following the crime

\section{Discussion}

\section{Applying the taxonomy}

The taxonomy can be deployed in two different ways: In a "law-to-taxonomy" approach, a piece of legislation is mapped onto the taxonomy, focusing initially on the illegal act(s) (e.g., Table 5). This can form part of a stock-taking exercise for identifying gaps or inconsistencies within a single country, or to enable international comparisons. Alternatively, in "taxonomy-to-law" approach an offence listed in the taxonomy is selected, and then identified across multiple countries. This facilitates like-for-like comparisons, and can be used to consider differences in which acts are legal or illegal across jurisdictions; the types of facets that shape the scope of the offences, and the sanctions associated with different acts and facets.

Table 5. "Law-to-taxonomy" analysis of two articles of the Kenya Wildlife Conservation and Management Act

\begin{tabular}{|c|c|c|c|}
\hline Act Article \& Paragraph & Taxonomy item & Taxonomy facet & Example observations \\
\hline $\begin{array}{l}\text { 93. Offences relating to } \\
\text { invasive species } \\
\text { Any person who- } \\
\text { (a) knowingly introduces an } \\
\text { invasive species into a } \\
\text { wildlife conservation area } \\
\text { an invasive species; or }\end{array}$ & $\begin{array}{l}\text { Introducing wildlife } \\
\text { invasive species into } \\
\text { wildlife habitats and } \\
\text { ecosystems (01-02-008- } \\
000)\end{array}$ & $\begin{array}{l}\text { Knowledge and } \\
\text { Intent: The facet of } \\
\text { "knowingly" is a } \\
\text { requirement for the act } \\
\text { to be a legal offence. } \\
\text { Offence Location: } \\
\text { Specifically into a } \\
\text { wildlife conservation } \\
\text { area }\end{array}$ & $\begin{array}{l}\text { Negligence is not a covered } \\
\text { Introducing invasive species } \\
\text { into sites that are not formally } \\
\text { protected is not covered. }\end{array}$ \\
\hline $\begin{array}{l}\text { (b) fails to comply with the } \\
\text { measures prescribed by the } \\
\text { Cabinet Secretary set out } \\
\text { under this Act, } \\
\text { commits an offence }\end{array}$ & $\begin{array}{l}\text { Other acts in violation } \\
\text { of the law related to } \\
\text { wildlife and wildlife } \\
\text { habitats conservation } \\
(01-99-000-000)\end{array}$ & NA & Very broad legal drafting \\
\hline $\begin{array}{l}\text { 95. Offences relating to } \\
\text { trophies and trophy dealing } \\
\text { Any person who, without a } \\
\text { permit or exemption } \\
\text { granted under this Act in } \\
\text { relation to a species not } \\
\text { specified under section } 92 \text { - } \\
\text { (a) kills or injures, tortures } \\
\text { or molests, or attempts to } \\
\text { kill or injure, any wildlife } \\
\text { species; }\end{array}$ & $\begin{array}{l}\text { Hunting without } \\
\text { authorization (02-02- } \\
000-000)\end{array}$ & $\begin{array}{l}\text { Victims' Legal Status: } \\
\text { Offences relate to } \\
\text { species that are not } \\
\text { protected (protected } \\
\text { species are covered by } \\
\text { Art. 92) }\end{array}$ & $\begin{array}{l}\text { Drafting language suggests that } \\
\text { there is a permitting process } \\
\text { that might enable torturing, } \\
\text { molesting and injuring wildlife, } \\
\text { which is presumably a mistake } \\
\text { in the Act. }\end{array}$ \\
\hline $\begin{array}{l}\text { (b) deals in a wildlife } \\
\text { trophy; }\end{array}$ & $\begin{array}{l}\text { Operating as a wildlife } \\
\text { trophy dealer without }\end{array}$ & NA & \\
\hline
\end{tabular}


authorization (06-02-

001-000)

\begin{tabular}{|c|c|c|c|}
\hline $\begin{array}{l}\text { (c) deals in a live wildlife } \\
\text { species; }\end{array}$ & $\begin{array}{l}\text { Trading wildlife } \\
\text { without authorization } \\
(07-02-000-000)\end{array}$ & $\begin{array}{l}\text { Form: Only applies to } \\
\text { live specimens }\end{array}$ & $\begin{array}{l}\text { Unclear how the law deals with } \\
\text { dead specimen that are not } \\
\text { considered trophies }\end{array}$ \\
\hline $\begin{array}{l}\text { (e) is in possession of a } \\
\text { wildlife trophy }\end{array}$ & $\begin{array}{l}\text { Possessing wildlife } \\
\text { trophies without } \\
\text { authorization (09-02- } \\
002-000)\end{array}$ & . & \\
\hline or live wildlife species; or & $\begin{array}{l}\text { Possessing wildlife } \\
\text { without authorization } \\
09-02-000-000\end{array}$ & $\begin{array}{l}\text { Form: Only applies to } \\
\text { live specimen }\end{array}$ & \\
\hline $\begin{array}{l}\text { (e) manufactures an item } \\
\text { from a wildlife trophy, } \\
\text { commits an offence and } \\
\text { shall be liable on } \\
\text { conviction to a fine of not } \\
\text { less than one } \\
\text { million shillings or a term } \\
\text { of imprisonment of not less } \\
\text { than twelve months or to } \\
\text { both such fine and } \\
\text { imprisonment. }\end{array}$ & $\begin{array}{l}\text { Processing items from } \\
\text { wildlife trophies } \\
\text { without authorization } \\
(06-02-003-000)\end{array}$ & NA & $\begin{array}{l}\text { Employs financial and } \\
\text { imprisonment sanctions } \\
\text { Sets minimum sanctions }\end{array}$ \\
\hline
\end{tabular}

Example: How do sanctions for hunting protected species differ across 8 countries?

There are laws regulating the hunting of protected species globally. However, approaches to sanctioning vary widely (Table 4). Understanding this requires not only parsing out laws of a single country (e.g., Table 5), but international comparison (e.g., Table 6). Amidst calls for strengthened legal responses to wildlife crime, a taxonomy-to-law approach revealed differences that could inform debates about what is necessary and appropriate across contexts.

We identified legislation related to the hunting of protected wildlife across 8 countries (Table 6). Each jurisdiction has 2-4 relevant laws that placed a range of sanctions. Most sanctions were fines and imprisonment, although there was significant variation. For example, minimum fines range from $\$ 0$ to nearly $\$ 200,000$, and maximum imprisonment terms range from 1.5 years to life imprisonment. Comparative analysis also revealed different approaches to sanctions (Table 6). For example, Costa Rica exclusively used imprisonment sanctions, and employed no monetary fines for the hunting protected species (fines only apply to hunting non-protected species). This likely reveals a comparatively strict, highly criminalised conservation approach, although the maximum imprisonment term was notably lower than other countries. Similarly, Kenya had both fixed fines and imprisonment for hunting protected species. 
Table 6. Sanctions across 8 countries for hunting protected wildlife (offence 02-01-000-000 and facet of "protected species")

\begin{tabular}{|c|c|c|c|c|c|c|c|c|c|}
\hline $\begin{array}{l}\text { Sanction } \\
\text { type }\end{array}$ & & Angola & Brazil & Cambodia & $\begin{array}{l}\text { Costa } \\
\text { Rica }\end{array}$ & Indonesia & Kenya & Mexico & Vietnam \\
\hline \multirow{2}{*}{$\begin{array}{l}\text { Admin. } \\
\text { fine }^{ \pm}\left(\$^{\ddagger}\right)\end{array}$} & Min & 900 & & 2,450 & & & 49,157 & 221 & 22 \\
\hline & Max & 1,800 & & 36,750 & & 6,988 & 196,628 & 308,722 & 21,500 \\
\hline \multirow[t]{2}{*}{$\begin{array}{l}\text { Crim. } \\
\text { fine }^{ \pm}\left(\$^{\uparrow}\right)\end{array}$} & Min & 22 & $\begin{array}{l}1,295 \text { per } \\
\text { specimen }\end{array}$ & & & & & 1,608 & 2,163 \\
\hline & Max & 133 & $\begin{array}{l}2,591 \text { per } \\
\text { specimen }\end{array}$ & & & & & 16,080 & 64,917 \\
\hline \multirow{2}{*}{$\begin{array}{l}\text { Prison } \\
\text { (Yrs) }\end{array}$} & Min & 0.5 & 0.8 & 1 & 1 & 0 & 5 & 1 & 0.5 \\
\hline & Max & 3 & 1.5 & 10 & 3 & 5 & Life & 9 & 5 \\
\hline
\end{tabular}

\section{Legal Sources:}

Angola: Forest and Wild Fauna Law, 2017; Decree on Hunting Ban, 2015; Decree on Hunting Fees and compensation to the State, 2016; Criminal Code, 2019

Brazil: Protected Areas Regulation, 1990-2009;Fauna Protection Law, 1967-2000; Law on Criminal and Administrative Sanctions on Activities Harming the Environment, 1988; Decree implementing Administrative Infractions and Sanctions to Environmental Offences, 2008

Cambodia: Forest and Wild Fauna Law, 2017; Decree on Hunting Ban, 2015; Decree on Hunting Fees and compensation to the State, 2016; Criminal Code, 2019

Costa Rica: Criminal Code 1970-2018; Wildlife Law 1992-2017

Indonesia: Conservation of Living Sources and the Ecosystems Act, 1990; Environmental Protection and Management Law, 2003

Kenya: Wildlife Conservation and Management Act No. 47 of 2013; Environmental Management and Coordination Act, 1999; Criminal Code 1930;

Mexico: Environmental Law, 1988-2018; Criminal Code, 1931-2018; Wildlife Law, 2000

Vietnam: Exploitation of Endangered Species Decree 2006; Forest Administrative Penalties Decree as amended in 2017;

Criminal Code as amended in 2017

₹ US dollar equivalent June 2019

${ }^{ \pm}$Admin. fines refers to administrative fines that involve non-criminal law, enforced and implemented by the executive power (e.g., Ministry of Environment) and does not require trial (e.g., fine for expired hunting permit); Crim. fines refers to criminal fines are included in the criminal code, implemented by a judicial power and require a trial and a court sentence.

Comparison further revealed that sanctions were defined by a range of aggravating and mitigating circumstances that vary across countries (Table 7). For example, fines in Mexico were conditional on the offender's salary, which could potentially increase the equity dimensions and deterrence of sanctions. Equally, they could be manipulated to enable lower sanctions for responsible parties who benefit significantly from environmental crime, or whose salary bears no relation to their actual wealth derived from illicit income. In Brazil, maximum sanctions only applied if the offender's motivation was for profit, providing need-greed distinctions (cf. Roe 2015) that may also speak to social equity concerns, but also potentially open up opportunities for manipulation. Economic sanctions were also allocated depending on the number of specimen, rather than per illegal act, potentially helping to ensure that the scale of sanctions better reflects the scale of harm and increasing deterrence (see Milner-Gulland and Leader-Williams 1992). In Cambodia, maximum sentencing applied only to cases within a protected area. This is likely problematic because protected biodiversity often exists outside of protected areas (Boakes et al. 2019), and that many seizures of wildlife occur along trade chains outside of protected areas. Cambodia also allowed for payment of fines to replace prison terms, which preferences wealthier perpetrators. Angola set fines based on the market values of wildlife, which conflates market values as a proxy for social, ecological and intrinsic values 
of wildlife. Through comparisons with other countries, the strengths, limitations and questions become especially evident.

Table 7. Notes on the sanctions that apply for "hunting protected wildlife" (taxonomy offence 02-01000-000 + "protected" facet), with reference to different aggravating and mitigating circumstances (see Table 9).

\begin{tabular}{|c|c|}
\hline Country & Notes on sanctions (conditions underlined) \\
\hline Angola & $\begin{array}{l}\text { - Fine equal to the market value of the animal } \\
\text { - Minimum and maximum values set for CITES-listed species }\end{array}$ \\
\hline Costa Rica & $\begin{array}{l}\text { - No fines } \\
\text { - Imprisonment is only set for hunting protected species. (Fines are only set for illegal } \\
\text { hunting of non protected species, which is a different offence in the taxonomy) }\end{array}$ \\
\hline Indonesia & $\begin{array}{l}\text { - No minimum fines or imprisonment are set } \\
\text { - Maximum fines and imprisonment only apply if the act was intentional }\end{array}$ \\
\hline Mexico & $\begin{array}{l}\text { - Fines are based on offender's salary } \\
\text { - Scale of fines depends on whether animal is alive or dead }\end{array}$ \\
\hline Cambodia & $\begin{array}{l}\text { - Financial sanctions can be in addition to, or a substitute for imprisonment } \\
\text { - Minimum sanctions only apply if the act involves a protected species, and maximum } \\
\text { only apply if the act involved a protected species within a protected area }\end{array}$ \\
\hline Brazil & $\begin{array}{l}\text { - Fines are set per specimen } \\
\text { - The maximum sanctions only apply if the act was motivated by profit. }\end{array}$ \\
\hline Vietnam & $\begin{array}{l}\text { - Between minimum and maximum fine limits, there is a detailed design of fine that } \\
\text { depends on a permutation that considers species protected status (Group I-B, II-B), } \\
\text { species value, and number of specimens. }\end{array}$ \\
\hline Kenya & $\begin{array}{l}\text { - Administrative fines and prison time for protected species are set depending on } \\
\text { species type. Lower penalty (minimum in the table) is set only for "Category B" } \\
\text { species and the higher penalty (maximum in the table) is set only for "Category A" } \\
\text { species. This includes mandatory life imprisonment_for hunting a "Category A". }\end{array}$ \\
\hline re w & $\begin{array}{l}\text { used on facets that define the offence, but there are also other factors that define the level of } \\
\text { e, number of specimen, offender salary). }\end{array}$ \\
\hline
\end{tabular}

\section{Conclusion}

Legal taxonomies can serve not only as organisational tools and decision-making tools (Law 2011), but also as instruments for identifying and articulating the approaches and elements that need reform (or revolution). This taxonomy provides a working draft for understanding and comparing wildlife offences globally that, as it is tested across contexts and for diverse uses, will likely require modification (cf. Land et al. 2013)

A number of recent, high-level policy events have called for strengthened conservation laws and enforcement in order to protect imperiled wildlife (e.g., Hanoi 2016; UK 2018; US 2019). These have clashed with concerns over how stricter rules affect livelihoods and rights (e.g., Masse et al. 2020). Our application of this taxonomy illustrates how these debates can gain from engaging the mechanics and nuances of domestic environmental law. 


\section{Acknowledgements}

This work was funded by the UK Government Defra's Illegal Wildlife Trade Challenge Grant to the WILDS Project. Thank you to E.L.Webb and R. Carmenta or their helpful comments.

\section{References}

1. ANSI/NISO Z39.19. 2005. Guidelines for the Construction, Format, and Management of Monolingual Controlled Vocabularies. Baltimore: National Information Standards Organization. URL: https://www.niso.org/publications/ansiniso-z3919-2005-2010.

2. Beyleveld, D., Brownsword, R. 1985. The practical difference between natural-law theory and legal positivism. Oxford Journal of Legal Studies 5:1-32.

3. Boakes, E.H., Fuller, R.A., McGowan, P.J., 2019. The extirpation of species outside protected areas. Conservation Letters 12:e12608.

4. Boratto, R., Gibbs, C. 2019. Advancing interdisciplinary research on illegal wildlife trade using a conservation criminology framework. European Journal of Criminology, p.1477370819887512.

5. Boyle, L. 2020, 10 April. The Independent calls for tighter restrictions on wildlife trade and markets. The Independent. URL: https://www.independent.co.uk/environment/wildlife-trade-market-banrestrictions-china-wuhan-a9459796.html.

6. Brockington, D., Duffy, R. 2019. The ethics of violent conservation. Blog for the BioSec Project, University of Sheffield. URL: https://biosecproject.org/2019/11/25/comment-the-ethics-of-violentconservation/.

7. Challender, D. W., Harrop, S. R., \& MacMillan, D. C. (2015). Towards informed and multi-faceted wildlife trade interventions. Global Ecology and Conservation, 3, 129-148.

8. (CCF) Cheetah Conservation Fund. 2019. Cheetah Conservation Fund Wins Grant From UK'S Illegal Wildlife Trade To Address Cheetah Trafficking in Horn of Africa/Gulf of Aden Region. URL: https://cheetah.org/press-releases/cheetah-conservation-fund-wins-grant-from-uks-illegal-wildlife-tradeto-address-cheetah-trafficking-in-horn-of-africa-gulf-of-aden-region/.

9. (CITES and UNEP) 2015, 05 May. CITES and UNEP support strengthening of wildlife laws. Convention on International trade of Endangered species of Fauna and Flora, United Nations Environmental Programme. URL:

https://www.cites.org/eng/CITES_UNEP_support_strengthening_of_wildlife_laws.

10. Cleaver, F. 2017. Development through bricolage: rethinking institutions for natural resource management. Routledge, U.K.

11. Chng, S.C., 2015. In the market for extinction: an inventory of Jakarta's bird markets. Traffic. URL: https://www.traffic.org/site/assets/files/2466/market_for_extinction_jakarta.pdf

12. Díaz, S., Demissew, S., Carabias, J., Joly, C., Lonsdale, M., Ash, N., Larigauderie, A., Adhikari, J.R., Arico, S., Báldi, A., Bartuska, A., 2015. The IPBES Conceptual Framework-connecting nature and people. Current Opinion in Environmental Sustainability 14:1-16.

13. Duffy, R., Massé, F., Smidt, E., Marijnen, E., Büscher, B., Verweijen, J., Ramutsindela, M., Simlai, T., Joanny, L. and Lunstrum, E. 2019. Why we must question the militarisation of conservation. Biological conservation 232:66-73.

14. Friedman, L. 2019, 12 Aug. U.S. Significantly Weakens Endangered Species Act. The New York Times. URL: https://www.nytimes.com/2019/08/12/climate/endangered-species-act-changes.html.

15. Garmestani, A., Ruhl, J.B., Chaffin, B.C., Craig, R.K., van Rijswick, H.F., Angeler, D.G., Folke, C., Gunderson, L., Twidwell, D. and Allen, C.R., 2019. Untapped capacity for resilience in environmental law. Proceedings of the National Academy of Sciences, 116(40), pp.19899-19904.

16. Gokkon, B. 2018, 06 April. Indonesian conservation bill is weak on wildlife crime, critics say. Mongabay. URL: https://indonesia.wcs.org/Initiatives/Wildlife-Policy.aspx

17. Harring, N., Jagers, S.C., Matti, S., 2019. The significance of political culture, economic context and instrument type for climate policy support: a cross-national study. Climate Policy 19:636-650.

18. ISO 25964-1:2011. Information and documentation - Thesauri and interoperatibility with other vocabulary. Part 1: Thesauri for information retrieval. 2017 Version. URL: https://www.iso.org/standard/53657.html.

19. (IUCN) International Union for Conservation of Nature. 2020. Global Species Programme. URL: https://www.iucn.org/theme/species/about/iucn-global-species-programme 
20. Keane, A., Jones, J.P., Edwards-Jones, G. and Milner-Gulland, E.J., 2008. The sleeping policeman: understanding issues of enforcement and compliance in conservation. Animal Conservation 11:75-82.

21. Kurland, J., Pires, S.F., McFann, S.C., Moreto, W.D. 2017. Wildlife crime: A conceptual integration, literature review, and methodological critique. Crime Science 6:4.

22. Land, L., Smith, S. Pang, V., 2013. June. Building a Taxonomy for Cybercrimes. Proceedings of the Asia Pacific Conference on Information Systems (p. 109). URL: http://aisel.aisnet.org/pacis2013/109.

23. Law, S., 2011. Epistemological considerations in private law: Exploring taxonomical structures in the Common Law, Civil Law and beyond. Maastricht Journal of European and Comparative Law 18:454478.

24. Massé, F., Dickinson, H., Margulies, J., Joanny, L., Lappe-Osthege, T., Duffy, R., 2020. Conservation and crime convergence? Situating the 2018 London Illegal Wildlife Trade Conference. Journal of Political Ecology 27:23-42.

25. Mattei, U., 1997. Three patterns of law: taxonomy and change in the world's legal systems. The American Journal of Comparative Law 45:5-44.

26. Milner-Gulland, E. J., Leader-Williams, N. 1992. A model of incentives for the illegal exploitation of black rhinos and elephants: Poaching pays in Luangwa Valley, Zambia. Journal of Applied Ecology 29:388-401.

27. Ostrom, E. 1990. Governing the commons: the evolution of institutions for collective action. Cambridge: Cambridge University Press.

28. Pennings, G., 2004. Legal harmonization and reproductive tourism in Europe. Human Reproduction 19:2689-2694.

29. Phelps, J., Shepherd, C. R., Reeve, R., Niissalo, M.A. Webb, E.L. 2014. No easy alternatives to conservation enforcement: Response to Challender and Macmillan. Conservation Letters 7:495-496.

30. Roe, D., 2015. Conservation, crime and communities: case studies of efforts to engage local. URL: https://www.researchgate.net/publication/276267349_Conservation_Crime_Communities_Case_studies _of_efforts_to_engage_local_communities_in_tackling_illegal_wildlife_trade.

31. Sherwin, E., 2009. Legal taxonomy. Legal Theory 15:25-54.

32. Spring, J. 2020, 22 May. Brazil minister calls for environmental deregulation while public distracted by COVID. URL: https://uk.reuters.com/article/us-brazil-politics-environment/brazilminister-calls-forenvironmental-deregulation-while-public-distracted-by-covid-idUKKBN22Y30Y

33. Thomson S.A., Pyle R.L., Ahyong S.T., Alonso-Zarazaga M., Ammirati J., Araya J.F., et al. 2018 Taxonomy based on science is necessary for global conservation. PLoS Biology 16(3): e2005075

34. TRAFFIC, the wildlife monitoring network. 2016. Legal loopholes leave non-native wildlife unprotected in Thailand. URL: https://www.traffic.org/news/legal-loopholes-leave-non-native-wildlife-unprotectedin-thailand/

35. WCO (World Customs Organization). 2020. What is the Harmonized System (HS)? URL:http://www.wcoomd.org/en/topics/nomenclature/overview/what-is-the-harmonized-system.aspx

36. (US) United States Department of State. 2019. END Wildlife Trafficking Report 2019. Bureau of Oceans and International Environmental and Scientific Affairs. URL: https://www.state.gov/2019-endwildlife-trafficking-report/

37. Hanoi statement on illegal wildlife trade 17-18 Nov. 2016, Hanoi, Vietnam. URL: http://iwthanoi.vn/wpcontent/uploads/2019/09/hanoi-statement-on-illegal-wildlife-trade.pdf

38. (UK) UK Government. 2019. Illegal Wildlife Trade Conference: London. 11-12 Oct., 2018, London. URL: https://www.gov.uk/government/topical-events/london-conference-on-the-illegal-wildlife-trade2018

39. Van Hoecke, M., Warrington, M., 1998. Legal cultures, legal paradigms and legal doctrine: towards a new model for comparative law. International \& Comparative Law Quarterly 47:495-536. 


\section{Supplementary Information}

Table S1. Types of legislation typically found in national jurisdictions as related to wildlife management and enforcement.

\begin{tabular}{|c|c|}
\hline Categories & Types of legislation \\
\hline $\begin{array}{l}\text { Domestic } \\
\text { trade related } \\
\text { legislation }\end{array}$ & $\begin{array}{l}\text { Constitutions } \\
\text { Overarching environmental protection } \\
\text { Endangered species } \\
\text { Forestry } \\
\text { CITES implementation legislation } \\
\text { Dedicated wildlife trade legislation } \\
\text { Wildlife management legislation } \\
\text { Hunting/fishing legislation } \\
\text { Wetlands legislation (e.g.., Ramsar Convention implementation) } \\
\text { World Heritage legislation (specifically the natural heritage elements) } \\
\text { Indigenous rights legislation } \\
\text { Manufacturing legislation (e.g., taxidermy, furs, pelt tanning) } \\
\text { Media and e-commerce legislation }\end{array}$ \\
\hline $\begin{array}{l}\text { Foreign } \\
\text { traderelated } \\
\text { legislation }\end{array}$ & $\begin{array}{l}\text { Free trade and/or transportation agreements } \\
\text { Bilateral agreements on mutual administrative assistance in customs matters } \\
\text { Import/export legislation } \\
\text { Quarantine legislation } \\
\text { Port authority legislation } \\
\text { Customs legislation } \\
\text { Maritime ports/airports legislation } \\
\text { Transportation authorities legislation }\end{array}$ \\
\hline $\begin{array}{l}\text { Enforcement, } \\
\text { judiciary and } \\
\text { prosecution } \\
\text { related } \\
\text { legislation }\end{array}$ & $\begin{array}{l}\text { Bi/multilateral agreements on judicial assistance or enforcement cooperation } \\
\text { Criminal law } \\
\text { Criminal procedure codes } \\
\text { Administrative law } \\
\text { Environmental liability legislation } \\
\text { Customs legislation } \\
\text { Police/customs/wildlife or CITES Management Authorities legislation } \\
\text { Environmental prosecutors and courts mandates } \\
\text { Organized crime legislation } \\
\text { Anti-Money laundering legislation } \\
\text { Anti-terrorism financing legislation } \\
\text { Anti-corruption legislation } \\
\text { Civil defense and military legislation } \\
\text { Firearms legislation } \\
\text { Transportation legislation (e.g., railway transport, inspection rules) }\end{array}$ \\
\hline $\begin{array}{l}\text { Wildlife uses } \\
\text { related } \\
\text { legislation }\end{array}$ & $\begin{array}{l}\text { Zoos/sanctuaries legislation } \\
\text { Captive breeding/farming for commercial purposes legislation } \\
\text { Personal or household effects/tourist souvenirs legislation } \\
\text { Traditional medicine legislation } \\
\text { Art and culture legislation } \\
\text { Pharmaceutical legislation } \\
\text { Commercial law }\end{array}$ \\
\hline
\end{tabular}


Table S2. List of sources and laws by country

\begin{tabular}{|c|c|c|}
\hline Country & Sources & Laws included in analysis \\
\hline Angola & $\begin{array}{l}\text { Coordination Cabinet for the } \\
\text { Urban Development of the } \\
\text { Cities of Kilamba, Camama and } \\
\text { Cacuarco (GCKCC) - } \\
\text { http://www.gckcc.ao } \\
\text { LegisPalop - https://www.legis- } \\
\text { palop.org } \\
\text { LEXLINK - } \\
\text { https://www.lexlink.eu/legislaca } \\
\text { o/angola } \\
\text { Private National Portal - } \\
\text { https://www.info-angola.com } \\
\text { South African Legal Information } \\
\text { Institute - } \\
\text { http://www.saflii.org/content/an } \\
\text { gola-index }\end{array}$ & $\begin{array}{l}\text { CITES Regulation, } 2013 \\
\text { Criminal Code (Bill), } 2006 \\
\text { Customs Code, 2006 } \\
\text { Environmental Law, } 1988 \\
\text { Forest and Wild Fauna Basic Law, } 2017 \\
\text { Law Criminalizing Infractions Related to Money } \\
\text { Laundering, 2014 } \\
\text { Prohibition of Trade, Transportation, Possession } \\
\text { and Exhibition of Protected Species, } 2016 \\
\text { Protected Species Hunting Ban, } 2015\end{array}$ \\
\hline Brazil & $\begin{array}{l}\text { Legal Portal of Presidential } \\
\text { Office - } \\
\text { https://legislacao.planalto.gov.br }\end{array}$ & $\begin{array}{l}\text { Anti-Money Laundering Law, 1988-2017 } \\
\text { Criminal Code, 1940-2018 } \\
\text { Decree on Administrative Infractions and } \\
\text { Sanctions to Environmental Offences, 2008-2017 } \\
\text { Fauna Protection Law, 1967-2000 } \\
\text { Law on Criminal and Administrative Sanctions } \\
\text { on Activities Harming the Environment, 1988- } \\
2014 \\
\text { Law on the National System for Conservation } \\
\text { Units, 2000 } \\
\text { Law on the Use of Animals for Scientific } \\
\text { Research, 2008 } \\
\text { National Environmental Policy, 1981-2015 } \\
\text { Organized Criminal Law, 2013-2016 } \\
\text { Protected Areas Law, 1981-1989 } \\
\text { Protected Areas Regulation 1990-2009 } \\
\text { Regulation on Banned Activities within } \\
\text { Protected Areas, 1989 } \\
\text { Regulation on the Inspection of Controlled } \\
\text { Items, 2018 }\end{array}$ \\
\hline Cambodia & $\begin{array}{l}\text { Council for Development of } \\
\text { Cambodia - } \\
\text { http://www.cambodiainvestment } \\
\text {.gov.kh/why-invest-in- } \\
\text { cambodia/laws-regulation.html } \\
\text { Central Department of Customs } \\
\text { and Excise of Cambodia - } \\
\text { http://www.customs.gov.kh/laws } \\
\text {-and-regulations/ } \\
\text { Cambodian Business Corner } \\
\text { https://cambodianbusinesscorner } \\
\text {.wordpress.com/2013/01/05/civi } \\
\text { l-code-2007/ }\end{array}$ & $\begin{array}{l}\text { Anti-Corruption Law, } 2010 \\
\text { Criminal Code, } 2009 \\
\text { Forestry Law, } 2002 \\
\text { Protected Areas Law, } 2008 \\
\text { Wildlife Protection Declaration, } 1996\end{array}$ \\
\hline
\end{tabular}




\begin{tabular}{|c|c|c|}
\hline & $\begin{array}{l}\text { Open Development Cambodia - } \\
\text { https://opendevelopmentcambod } \\
\text { ia.net/database/laws-policies- } \\
\text { and-agreements/ } \\
\text { SK\&P Cambodia Law Group - } \\
\text { http://www.skpcambodia.com/la } \\
\text { ws-and-regulations-of-kingdom- } \\
\text { of-cambodia.html } \\
\text { WIPO Lex - } \\
\text { https://www.wipo.int/wipolex/e } \\
\text { n/ }\end{array}$ & \\
\hline Costa Rica & $\begin{array}{l}\text { National Legal Information } \\
\text { System - www.pgrweb.go.cr }\end{array}$ & $\begin{array}{l}\text { Animal Welfare Law, 1994-2017 } \\
\text { Anti-Corruption Law, 2004-2016 } \\
\text { Criminal Code, 1970-2018 } \\
\text { Customs Law, 1995-2015 } \\
\text { Firearms and Explosives Law, 1995-2011 } \\
\text { National Park Law, 1977 } \\
\text { Organized Crime Law, } 2009 \\
\text { Wildlife Conservation Law, 1992-2017 } \\
\text { Wildlife Conservation Regulation, } 2017 \\
\end{array}$ \\
\hline Indonesia & $\begin{array}{l}\text { Information System of the } \\
\text { Directorate General of Laws and } \\
\text { Regulations - } \\
\text { http://ditjenpp.kemenkumham.g } \\
\text { o.id/ } \\
\text { International Labour } \\
\text { Organization - } \\
\text { https://www.ilo.org/dyn/natlex/ }\end{array}$ & $\begin{array}{l}\text { Animal, Fish, and Plant Quarantine Law, } 1992 \\
\text { Anti-Corruption Law, } 1999 \\
\text { Anti-Money Laundering Law, } 2010 \\
\text { Conservation of Living Resources and their } \\
\text { Ecosystems Act, } 1990 \\
\text { Criminal Code, } 1999 \\
\text { Customs Code (2006 Amendment) } \\
\text { Customs Code, } 1995 \\
\text { Electronic Information and Transaction Law, } \\
2008 \\
\text { Forestry Affairs Act, } 1999 \\
\text { Game Hunting Affairs Government Regulation, } \\
1994 \\
\text { Management of the Living Environment Act, } \\
1982 \\
\text { Trade Law, } 2014 \\
\text { Utilization of Plants and Wildlife Regulation, } \\
1999\end{array}$ \\
\hline Kenya & $\begin{array}{l}\text { National Council for Law } \\
\text { Reporting - } \\
\text { http://kenyalaw.org/lex//index.x } \\
\text { ql }\end{array}$ & $\begin{array}{l}\text { Animal Diseases Act, 1965-2012 } \\
\text { Anti-Corruption and Economic Crimes Act, } \\
2003-2016 \\
\text { Bribery Act, } 2016 \\
\text { Computer Misuse and Cybercrimes Act, } 2018 \\
\text { Customs and Excise Act, 1978-2013 } \\
\text { Firearms Act, 1953-2015 } \\
\text { Penal Code, 1930-2014 } \\
\text { Prevention of Cruelty to Animals (Transport of } \\
\text { Animals) Regulations, } 1984 \\
\text { Prevention of Cruelty to Animals Act, 1962- } \\
\text { 2012 } \\
\text { Prevention of Organized Crimes Act, 2010 } \\
\text { Proceeds of Crime and Anti-Money Laundering } \\
\text { Act, 2009-2017 }\end{array}$ \\
\hline
\end{tabular}


Proceeds of Crime and Anti-Money Laundering

Regulation, 2013

Protected Areas Act, 1949-1964

Tourism Act, 2011-2014

Trade Description Act, 1977-2003

Wildlife Conservation and Management Act, 2013

\begin{tabular}{|c|c|c|}
\hline Mexico & $\begin{array}{l}\text { Congress of the Union - } \\
\text { www.diputados.gob.mx/LeyesBi } \\
\text { blio/index.htm }\end{array}$ & $\begin{array}{l}\text { Administrative Responsibilities Law, } 2016 \\
\text { Animal Health Law, 2007-2018 } \\
\text { Animal Slaughtering Norm, } 2014 \\
\text { Criminal Code, 1931-2018 } \\
\text { Customs Law, 1995-2018 } \\
\text { Environmental Law, 1988-2018 } \\
\text { Forestry Regulation, 2005-2014 } \\
\text { Humanitarian Transportation Norm, } 1995 \\
\text { Organized Crime Law, 1996-2017 } \\
\text { Protected Areas Regulation, 2000-2014 } \\
\text { Weapons and Explosive Law, 1972-2015 } \\
\text { Wildlife Law, 2000-2018 }\end{array}$ \\
\hline Vietnam & $\begin{array}{l}\text { Ministry of Justice Legal } \\
\text { Database - } \\
\text { http://vbpl.vn/TW/Pages/vbpqen } \\
\text {.aspx } \\
\text { Laws of Law Library - } \\
\text { https://thuvienphapluat.vn/en/ }\end{array}$ & $\begin{array}{l}\text { Anti-Corruption Law, } 2015 \\
\text { Anti-Money Laundering Law, } 2012 \\
\text { Biodiversity Law, } 2008 \\
\text { Circular on Common Wildlife Management, } \\
2012 \\
\text { Circular on Criminal Code Guidelines (Forest } \\
\text { Violations), } 2007 \\
\text { CITES Implementing Decree, } 2006 \\
\text { Criminal Code, 2015-2017 } \\
\text { Environmental Administrative Violations } \\
\text { Decree, } 2013 \\
\text { Decree on Goods Banned From Business, } 2006 \\
\text { Endangered Species Decree, } 2013 \\
\text { Environmental Protection Law, } 2014 \\
\text { Exploitation of Endangered Species Decree, } \\
2006 \\
\text { Forest Administrative Penalties Decree, 2013- } \\
2017 \\
\text { Forestry Law } 2017\end{array}$ \\
\hline & \multicolumn{2}{|c|}{$\begin{array}{l}\text { Boratto, R., Gibbs, C. 2017. Wildlife Crime. Oxford Research Encyclopedia of } \\
\text { Criminology and Criminal Justice } \\
\text { Crow, M.S., Shelley, T.O., Stretesky, P.B. 2013. Camouflage-Collar Crime: An } \\
\text { Examination of Wildlife Crime and Characteristics of Offenders in Florida. Deviant } \\
\text { Behavior 34:8, 635-652 } \\
\text { Gottschalk, P. 2010. Categories of Financial Crime. Journal of Financial Crime. } \\
\text { 17:14, 441-458 } \\
\text { Nurse, A. 2011. Policing wildlife: perspectives on criminality in wildlife crime. } \\
\text { Papers from the British Criminology Conference. 11 . pp. 38-53. ISSN 1759-0043 } \\
\text { UNODC (United Nations Office on Drugs and Crime). 2012. Wildlife and Forest } \\
\text { Crime Analytic Toolkit. } \\
\text { URL: https://www.unodc.org/documents/Wildlife/Toolkit_e.pdf } \\
\text { UNODC (United Nations Office on Drugs and Crime). 2015. International } \\
\text { Classification of Crime for Statistical Purposes. }\end{array}$} \\
\hline
\end{tabular}


URL: https://www.unodc.org/documents/data-and

analysis/statistics/crime/ICCS/ICCS_English_2016_web.pdf

UNODC (United Nations Office on Drugs and Crime). 2018. Guide on Drafting

Legislation to Combat Wildlife Crime

URL: https://sherloc.unodc.org/res/cld/guide-on-drafting-legislation-to-combatwildlife-crime html/Wildlife Crime ebook.pdf

Viollaz, J., Graham, J., Lantsman, L. 2018. Using script analysis to understand the financial crimes involved in wildlife trafficking. Crime, Law and Social Change. 
Table S3. Protocols for addressing common challenges when identifying candidate terms in legislation

\begin{tabular}{|c|c|c|c|}
\hline \multicolumn{2}{|r|}{ Protocol } & \multicolumn{2}{|c|}{ Example } \\
\hline Step & Explanation & $\begin{array}{l}\text { Offence as articulated in } \\
\text { legislation }\end{array}$ & $\begin{array}{l}\text { Candidate } \operatorname{term}(\mathrm{s}) \\
\text { extracted for the dataset }\end{array}$ \\
\hline $\begin{array}{l}\text { Focusing on } \\
\text { the unlawful } \\
\text { act. }\end{array}$ & $\begin{array}{l}\text { Sentence-like structures in law } \\
\text { were converted to candidate terms, } \\
\text { starting with the gerund form of } \\
\text { the verb to ensure that the focus } \\
\text { remained on a singularly } \\
\text { identifiable act }\end{array}$ & $\begin{array}{l}\text { Those who enter a protected area } \\
\text { carrying a hunting gun }\end{array}$ & $\begin{array}{l}\text { Carrying a gun inside a } \\
\text { protected area }\end{array}$ \\
\hline $\begin{array}{l}\text { Additional } \\
\text { offence } \\
\text { elements. }\end{array}$ & $\begin{array}{l}\text { Candidate terms did not include } \\
\text { legal elements defining } \\
\text { exceptions, and aggravating or } \\
\text { mitigating circumstances for an } \\
\text { offence. } \\
\text { These elements provide relevant } \\
\text { limitations to an offence, however, } \\
\text { ventured beyond the scope of this } \\
\text { core wildlife offence taxonomy.. }\end{array}$ & $\begin{array}{l}\text { Indonesia's 'Conservation of Living } \\
\text { Resources and the Ecosystems Act, } \\
\text { No. } 5 \text { of } 1990 \text { ': } \\
\text { Article } 21(2)(\text { a): Any and all } \\
\text { persons are prohibited to catch, } \\
\text { injure, kill, keep, possess, care for, } \\
\text { transport, and trade in a protected } \\
\text { animal in live condition. } \\
\text { Exception: } \\
\text { Article } 22(1) \text { : Any exception from } \\
\text { the prohibition pertaining to Article } \\
21 \text { can only be permitted for } \\
\text { purposes of research, science, } \\
\text { and/or safeguarding those plants or } \\
\text { animals. } \\
\text { Mitigating: } \\
\text { Article } 22(3): \text { An exception to the } \\
\text { prohibition to catch, to injure, or to } \\
\text { kill a protected animal can only be } \\
\text { permitted in case the animal } \\
\text { endangers human life. }\end{array}$ & $\begin{array}{l}\text { Offence Exemption: if is for } \\
\text { scientific or research } \\
\text { purposes or if to safeguard } \\
\text { animals } \\
\text { Offence Mitigating } \\
\text { circumstance: in the case the } \\
\text { animal endangers human life, }\end{array}$ \\
\hline $\begin{array}{l}\text { Repetition of } \\
\text { offences. }\end{array}$ & $\begin{array}{l}\text { When offences were repeated } \\
\text { within legislation, they were } \\
\text { recorded in the dataset only once } \\
\text { per piece of legislation, in order to } \\
\text { inform the selection of preferred } \\
\text { (versus non-preferred/synonym) } \\
\text { terms. }\end{array}$ & & \\
\hline $\begin{array}{l}\text { Aggregation } \\
\text { of illegal acts. }\end{array}$ & $\begin{array}{l}\text { When a piece of legislation listed } \\
\text { several acts into one provision, } \\
\text { these were each treated as a } \\
\text { separate candidate term }\end{array}$ & $\begin{array}{l}\text { Indonesia's 'Conservation of Living } \\
\text { Resources and the Ecosystems Act, } \\
\text { No. } 5 \text { of 1990': } \\
\text { Article 21(2)(a): Any and all } \\
\text { persons are prohibited to catch, } \\
\text { injure, kill, keep, possess, care for, } \\
\text { transport, and trade in a protected } \\
\text { animal in live condition. }\end{array}$ & $\begin{array}{l}\text { Catching a live protected } \\
\text { animal } \\
\text { Injuring a live protected } \\
\text { animal } \\
\text { Killing a live protected } \\
\text { animal } \\
\text { Keeping a live protected } \\
\text { animal } \\
\text { Possessing a live protected } \\
\text { animal }\end{array}$ \\
\hline
\end{tabular}


Caring for a live protected animal

Transporting a live protected animals Trading a live protected animal

$\begin{array}{ll}\begin{array}{l}\text { Elimination } \\ \text { of extraneous }\end{array} & \begin{array}{l}\text { Specific references to a country's } \\ \text { name or title were replaced with a }\end{array} \\ \text { elements. } & \text { generic phrase. }\end{array}$
elements.
Canada's 'Wild Animal and Plant

Protection and Regulation of

International and Interprovincial

Trade Act, 1992':

Article 6(1): No person shall import

into Canada any animal or plant

that was taken, or any animal or

plant, or any part or derivative of an

animal or plant, that was possessed,

distributed or transported in

contravention of any law of any

foreign state.

... in violation of the Hunting Law provisions
Importing any animal possessed, distributed or transported in contravention of any foreign state
Indonesia's 'Forestry Affairs Act, No. 41 of 1999':

Article 78(7): Whoever deliberately violates the provision as meant in Article 50 sub section (3) letter $h$ will be threatened with the punishment of a maximum imprisonment of 5 (five) years and a maximum fine of $R p$ 10,000,000,000.oo (ten billion rupiah).

Articles 50(3)(h): Everyone is prohibited to transport, control or own forest products not covered by a certificate on the legality of the forest products

$\begin{array}{ll}\text { Handling } & \text { When provisions in a piece of } \\ \text { linked } & \text { legislation are linked and, in } \\ \text { references. } & \begin{array}{l}\text { combination, constitute an } \\ \text { offence, the candidate term was } \\ \text { generated by combining the linked } \\ \text { provisions. }\end{array}\end{array}$

Mexico's 'Federal Animal Health Law, 2007':

Article $167(X X)$ : Violations of the provisions of this Law and other provisions arising therefrom will be sanctioned administratively by the Secretariat, without prejudice to the corresponding penalties when they constitute crimes. These are administrative infractions:
... in violation of the law

Transporting forest products not covered by a certificate on the legality of the forest products Controlling forest products not covered by a certificate on the legality of the forest products

Owning forest products not covered by a certificate on the legality of the forest products

Transportation of live animals or animal products involving zoo sanitary or sanitary risk not following legal requirements 
Failure to comply with the provisions relating to article 70 of this Law

Article 70: The Secretariat shall determine, through animal health provisions, the characteristics, requirements or specifications that must be met by vehicles and the transportation of live animals, goods of animal origin and products for animal use or consumption, when they involve a animal health risk or, where appropriate, a risk. of contamination of goods of animal origin.

Recording catch-all offences.
In situations where the offence section of a piece of legislation contained a general offence penalizing any violation of provisions in that law, the candidate term(s) were determined as either:

- If the law contained a list of specifically prohibited acts, these were converted to candidate terms per the rest of the applied protocol steps.

- If no such specific list existed, the candidate term used the phrase "breach/violation of the rules of..."
Mexico's 'Norm NOM-051-ZOO- Violation of the rules of 1995 on the Humanitarian humanitarian treatment Treatment of Wildlife during transportation of Transportation': wildlife.

Article 8: Failure to comply with the provisions contained in this Norm will be sanctioned in accordance with the provisions of the Federal Animal Health Law and the Federal Law on Metrology and Standardization. 
Table S4. List of candidate terms and the frequency with which they appeared in the dataset. Bold indicates selected term used in the taxonomy, followed by synonyms (not in bold). "_" indicates that term was from the Thesaurus.

\begin{tabular}{|c|c|c|c|}
\hline Term & Frequency & Term & Frequency \\
\hline Ammunition & 27 & Wildlife & 236 \\
\hline Cartridges & 4 & Species & 174 \\
\hline Gunpower & 3 & Wildlife Species & 83 \\
\hline Munition & - & Fauna & 82 \\
\hline Bullets & - & Animals & 76 \\
\hline Breeding & 60 & Wild Animals & 69 \\
\hline Nurture/Nurturing & 2 & Forest Animals & 29 \\
\hline Grown/Growing & 1 & Game & 7 \\
\hline Farm/Farming & 1 & Wild Species & 7 \\
\hline Rear/Rearing & 1 & Fauna Species & 5 \\
\hline Fosterage/Fostering & - & Common Species & 5 \\
\hline Multiplication/Multiplying & - & Biota Species & 1 \\
\hline Procreation/Procreating & - & Game Species & 1 \\
\hline Propagation/Propagating & - & Wildlife Animals & 1 \\
\hline Upbring/Upbringing & - & Wildlife Management Site & 12 \\
\hline Conceal/Concealing & 24 & Wildlife Refuge & 3 \\
\hline Hide/Hiding/Hidden & 6 & Wildlife Reserve & 2 \\
\hline Mask/Masking & - & Game Reserve & 2 \\
\hline Protected & 136 & Use/Using & 27 \\
\hline Endangered & 86 & Consumption/Consuming & 5 \\
\hline Rare & 70 & Enjoyment/Enjoying & - \\
\hline Threatened & 37 & Spend/Spending & - \\
\hline Precious & 19 & Weapon & 45 \\
\hline Listed & 14 & Firearm & 39 \\
\hline Prohibited & 12 & Arm & 2 \\
\hline CITES Listed & 6 & Gun & 1 \\
\hline Controlled & 1 & Transportation/Transporting & 83 \\
\hline Flagship & 1 & Carriage/Carrying & 27 \\
\hline Exotic (Wildlife) & 14 & Transfer/Transferring & 11 \\
\hline Alien & 4 & Transit/Transiting & 3 \\
\hline Non-native & 1 & Shipment/Shipping & 3 \\
\hline Foreign & - & Deliver/Delivering & 2 \\
\hline Export/Exporting & 73 & Mobilization/Mobilizing & 2 \\
\hline Removal/Removing & 5 & Convey/Conveying & - \\
\hline
\end{tabular}




\begin{tabular}{|c|c|c|c|}
\hline Selling abroad & - & Freightage & - \\
\hline Market abroad & - & Movement/Moving & - \\
\hline Market overseas & - & Storage/Storing & 11 \\
\hline Send abroad & - & Deposit/Depositing & 5 \\
\hline Shipping out & - & Stock/Stocking & 5 \\
\hline Foreign Commerce & 14 & Have in custody & - \\
\hline Foreign Trade & 5 & Slack & - \\
\hline $\begin{array}{l}\text { International Commercial } \\
\text { Transaction }\end{array}$ & 4 & Pile & - \\
\hline International Trade & 3 & Collect & - \\
\hline Harass/Harassing & 21 & Trade/Trading & 79 \\
\hline Exhaust/Exhausting & 2 & Commercial Exploitation & 17 \\
\hline Tease/Teasing & - & Traffic/Trafficking & 12 \\
\hline Torment/Tormenting & - & Deal/Dealing & 7 \\
\hline Interfere/Interfering & - & Country Commerce & 5 \\
\hline Disturb/Disturbing & - & Exchange/Exchanging & 4 \\
\hline Fatigue/Fatiguing & - & Commercialization & 3 \\
\hline Annoy/Annoying & - & Commercial Transaction & 3 \\
\hline Hunt/Hunting & 152 & Commercial Trade & 1 \\
\hline Take/Taking & 46 & Sale/Selling & 26 \\
\hline Collect/Collecting & 26 & Offer/Offering for Sale & 3 \\
\hline Kill/Killing & 25 & Transfer/Transferring & 3 \\
\hline Capture/Capturing & 22 & Market/Marketing & 3 \\
\hline Trap/Trapping & 13 & Peddle/Peddling & - \\
\hline Catch/Catching & 12 & Put on Sale & - \\
\hline Slaughter/Slaughtering & 6 & Purchase/Purchasing & 14 \\
\hline Gather/Gathering & 3 & Acquisition/Acquiring & 13 \\
\hline Remove/Removing & 3 & Receival/Receiving & 6 \\
\hline Eliminate/Eliminating & 2 & Procurement/Procuring & 3 \\
\hline Shoot/Shooting & 1 & Obtain/Obtaining & 3 \\
\hline Wound/Wounding & 1 & Buy/Buying & 1 \\
\hline Nets/Netting & - & Attainment/Attain & - \\
\hline Bait/Baiting & - & Bargain for & - \\
\hline Poison/Poisoning & - & Barter for & - \\
\hline Lure/Luring & - & Contract for & - \\
\hline Import/Importing & 103 & Pay for & - \\
\hline $\begin{array}{l}\text { Introduction/Introducing to } \\
\text { country }\end{array}$ & 37 & Shop for & - \\
\hline
\end{tabular}




\begin{tabular}{ll|ll} 
Bring into country & 1 & Protected Area & 36 \\
Bringing in & - & Conservation Area & 20 \\
Shipping in & - & National Park & 17 \\
Sourcing from abroad & - & National Reserve & 6 \\
Bringing from abroad & - & Protected Zone & 2 \\
Buying from abroad & - & Protected Ecosystem & 2 \\
\hline Native (Wildlife) & 25 & Biological Reserve & 1 \\
Endemic & 6 & Nature Reserve & 1 \\
Indigenous & - & Process/Processing & 12 \\
\hline Performance/Performing & 12 & Transformation/Transforming & 5 \\
Exhibition/Exhibiting & 4 & Manufacture/Manufacturing & 3 \\
Demonstration/Demonstrating & 2 & Fabricate/Fabricating & - \\
Show/Showing & 2 & Prepare/Preparing & - \\
Display/Displaying & 1 & Produce/Producing & - \\
Showcase/Showcasing & - & Make/Making & - \\
\hline Possession/Possessing & 83 & & \\
Cage/Caging & 2 & & \\
Hold/Holding & - & & \\
Impark/Imparking & - & & \\
Have/Having & - & \\
Keep/Keeping & & \\
Maintain/Maintaining & - & \\
Own/Owning & - & \\
Retain/Retaining & & \\
\hline
\end{tabular}

